\title{
PRODUCT QUALITY CONTROL USING SIX SIGMA (DMAIC) METHODS TO MINIMIZE WAST IN BIMA MANDIRI CIGARETTE COMPANY REMBANG, PASURUAN REGENCY
}

\author{
Muhammad Husen $^{1 *}$, Dayal Gustopo ${ }^{2}$, Dimas Indra Laksmana ${ }^{3}$ \\ ${ }^{1}$ Bineka Tunggal Ika Yunior High School, Pasuruan, Indonesia \\ ${ }^{2,3}$ Industrial Engineering, National Institute of Technology (ITN) Malang, Indonesia
}

*Corresponding Email: van.haushen@gmail.com

\begin{abstract}
Quality is a key to be able to compete in the industrial world [16. Quality control is needed to reduce the number of defective products produced by the company, thus reducing losses experienced by the company. The Bima Mandiri Rembang Pasuruan cigarette company is a company that produces cigarettes, one of which is INNO cigarettes. The number of defective products produced by the company so that the company must make an increase in quality by using a method to reduce the number of defects that occur. The number of defective products causes the company to suffer losses. For that, we need a method that can reduce cigarette defective products which in turn can improve the quality of the company's production. Six Sigma with the DMAIC stage (Define, Measure, Analyze, Improve, Control) is a method used in this research. Based on these steps, defects that often occur are less dense cigarettes as many as 289 sticks with a percentage of $25 \%$, tearing on the cigarettes as many as 227 cigarettes with a percentage of $20 \%$ and peeling cigarettes as many as 208 sticks with a percentage of $18 \%$. Factors that cause defects include humans, machines, methods and materials. After calculating using the Six Sigma method, before the improvement, the DPMO value is 113988.1 and the Sigma Level value is 2.722. After the improvements were made, the DPMO value decreased to 76488.1 and the Sigma Level was 2.94715. To achieve the six sigma target, the company is expected to be able to carry out improvements with a focus on the factors that cause product defects and always carry out regular control to reduce product defects. The corrective steps taken in the Bima Mandiri Rembang Pasuruan Regency cigarette company are human: regular training for machine operators and employees; methods: inspection of raw materials, blending machines and glue residue in the teat; engine: inspection of engine components; material: reprocessing less refined raw materials and using better quality glue.
\end{abstract}

Keywords: Quality control, Six Sigma, DMAIC

\section{Introduction}

The development of the cigarette industry from year to year is increasingly rapid, in line with advances in supporting technology for the increasingly modern cigarette industry[1]. The progress and development of the times is able to change the way consumers look at choosing a desired product[2]. Quality is very important in choosing a product in addition to the competitive price factor. To maintain their products from being competed by other industries, quality standards are needed[3]. Quality quality attracts consumer attention to buy a product. That way to attract consumers. these products must have quality standards in accordance with consumer desires[4]. To achieve a quality product, companies must always control and improve the quality of their products, so that you will get perfect results. For this reason, the company must always make a quality selection of the products produced by reducing the number of defective products[5]
The Bima Mandiri Rembang Pasuruan cigarette company is a company engaged in manufacturing. This company produces several types of cigarettes, one of which is INNO cigarettes. In its production, this company always produces defective products, Disability that occurs is more than one type of disability, including loose ends of cigarettes, length of cigarette not according to standard (cigarette not cut), Broken (loose filter), less dense, torn on cigarette, and peeling. In this case the company must carry out quality control so as to produce a really high quality product so that it is accepted by consumers[6].

This study aims to minimize wast at the Bima Mandiri Cigarette Company Rembang Pasuruan using the six sigmma method with the DMAIC stage[7]. So as to produce products with good quality and continue to increase. 


\section{Resarch Method}

This research is a type of quantitative and observational research. Sampling using random techniques. The types of data used in this study are quantitative data, polymer data and secondary data. while for data collection techniques by means of interviews and observations. The instruments used were interviews and observation. Interviews were conducted with company owners and employees, this method is used to obtain primary data in the form of data on the number of products, the causes of product defects. The next instrument is observation, Observations made are direct observations of the object to be studied, namely in the form of inno cigarette production, as well as checking data and facts in the field, observations are also made on employees to find out firsthand about the employees' work abilities. The data analysis technique uses the six sigma method with DMAIC stages[8].

is not cut), Broken (loose filter), less dense, Tears on the cigarette, Peeling on the cigarette.

\section{Results and Discussion}

\section{a. Define}

The first stage in Six Sigma analysis is the define stage. In the define stage, identification will be carried out related to the problem of damage to Inno cigarette products. From the results of observations during sampling from the production results, the following product defects were found: Lumpy cigarettes, the length of the cigarette does not match the standard (the cigarette is not cut), Broken (loose filter), less dense, Tears on the cigarette, Peeling on the cigarette[9].

\section{b. Measure}

In this stage, measurements and calculations are made of the research data. At this stage, the calculation of the number of defective products, the DPMO value and the sigma level is carried out [10].

a. Data calculation of the number of defective products during sampling.

Table 1 The number of defective products according to the number of samples examined

\begin{tabular}{|c|c|c|c|c|c|c|c|}
\hline \multirow{2}{*}{ Sample } & \multicolumn{6}{|c|}{ Type of defect } & \multirow{2}{*}{ amount } \\
\hline & $\mathrm{A} 1$ & $\mathrm{~A} 2$ & A3 & A4 & A5 & A6 & \\
\hline 336 & 13 & - & - & 10 & 1 & 7 & 31 \\
\hline 336 & 7 & 9 & - & 7 & 18 & 11 & 52 \\
\hline 336 & 2 & 5 & 10 & 8 & 22 & - & 47 \\
\hline 336 & - & 4 & - & 5 & 3 & 21 & 33 \\
\hline 336 & 11 & 18 & 8 & 3 & 11 & - & 51 \\
\hline 336 & & 21 & 2 & 5 & - & 3 & 31 \\
\hline 336 & 2 & - & 4 & 13 & 5 & 14 & 38 \\
\hline 336 & 7 & - & - & 7 & 13 & 8 & 35 \\
\hline 336 & 11 & 6 & - & 7 & 22 & & 46 \\
\hline 336 & 3 & 3 & 2 & - & 5 & 10 & 23 \\
\hline 336 & 12 & - & 7 & 8 & 4 & 7 & 38 \\
\hline 336 & - & 9 & - & 11 & 6 & 5 & 31 \\
\hline 336 & 15 & 11 & & - & 4 & & 30 \\
\hline 336 & 13 & - & 11 & 14 & 10 & 5 & 53 \\
\hline 336 & 6 & 1 & 1 & 16 & - & 3 & 27 \\
\hline 336 & - & - & 3 & 8 & 8 & 9 & 28 \\
\hline 336 & 8 & 8 & 6 & 20 & 11 & - & 53 \\
\hline 336 & 10 & 8 & - & 1 & 5 & 17 & 41 \\
\hline 336 & 5 & 9 & & 20 & - & 12 & 46 \\
\hline 336 & - & 5 & 11 & 22 & 8 & 5 & 51 \\
\hline 336 & & - & 1 & 7 & 4 & 16 & 28 \\
\hline 336 & 12 & 3 & 5 & - & 15 & 7 & 42 \\
\hline 336 & 8 & - & - & 8 & 8 & 8 & 32 \\
\hline 336 & & 10 & 6 & 6 & 4 & - & 26 \\
\hline 336 & 3 & 4 & 9 & 17 & 10 & 11 & 54 \\
\hline 336 & & 7 & - & 28 & 6 & 10 & 51 \\
\hline 336 & 13 & 3 & 8 & 13 & 14 & - & 51 \\
\hline 336 & & - & & 7 & 8 & 6 & 21 \\
\hline 336 & 7 & 2 & 3 & 18 & - & 3 & 33 \\
\hline 336 & 4 & - & 10 & - & 2 & 10 & 26 \\
\hline 10.080 & 172 & 146 & 107 & 289 & 227 & 208 & 1.149 \\
\hline
\end{tabular}


b. Calculation of DPMO value and sigma level

Table 2 DPMO values and Sigma levels of inno cigarettes

\begin{tabular}{|c|c|c|c|c|c|}
\hline $\begin{array}{l}\text { Observation } \\
\text { to }\end{array}$ & Sample & $\begin{array}{l}\text { number } \\
\text { of } \\
\text { defects }\end{array}$ & DPO & DPMO & $\begin{array}{l}\text { LEVEL } \\
\text { SIXMA }\end{array}$ \\
\hline 1 & 336 & 31 & 0,092262 & 92261,9 & 2,827 \\
\hline 2 & 336 & 52 & 0,154762 & 154761,9 & 2,516 \\
\hline 3 & 336 & 47 & 0,139881 & 139881 & 2,581 \\
\hline 4 & 336 & 33 & 0,098214 & 98214,29 & 2,792 \\
\hline 5 & 336 & 51 & 0,151786 & 151785,7 & 2,529 \\
\hline 6 & 336 & 31 & 0,092262 & 92261,9 & 2,827 \\
\hline 7 & 336 & 38 & 0,113095 & 113095,2 & 2,710 \\
\hline 8 & 336 & 35 & 0,104167 & 104166,7 & 2,758 \\
\hline 9 & 336 & 46 & 0,136905 & 136904,8 & 2,594 \\
\hline 10 & 336 & 23 & 0,068452 & 68452,38 & 2,987 \\
\hline 11 & 336 & 38 & 0,113095 & 113095,2 & 2,710 \\
\hline 12 & 336 & 31 & 0,092262 & 92261,9 & 2,827 \\
\hline 13 & 336 & 30 & 0,089286 & 89285,71 & 2,845 \\
\hline 14 & 336 & 53 & 0,157738 & 157738,1 & 2,504 \\
\hline 15 & 336 & 27 & 0,080357 & 80357,14 & 2,903 \\
\hline 16 & 336 & 28 & 0,083333 & 83333,33 & 2,883 \\
\hline 17 & 336 & 53 & 0,157738 & 157738,1 & 2,504 \\
\hline 18 & 336 & 41 & 0,122024 & 122023,8 & 2,665 \\
\hline 19 & 336 & 46 & 0,136905 & 136904,8 & 2,594 \\
\hline 20 & 336 & 51 & 0,151786 & 151785,7 & 2,529 \\
\hline 21 & 336 & 28 & 0,083333 & 83333,33 & 2,883 \\
\hline 22 & 336 & 42 & 0,125 & 125000 & 2,650 \\
\hline 23 & 336 & 32 & 0,095238 & 95238,1 & 2,809 \\
\hline 24 & 336 & 26 & 0,077381 & 77380,95 & 2,923 \\
\hline 25 & 336 & 54 & 0,160714 & 160714,3 & 2,492 \\
\hline 26 & 336 & 51 & 0,151786 & 151785,7 & 2,529 \\
\hline 27 & 336 & 51 & 0,151786 & 151785,7 & 2,529 \\
\hline 28 & 336 & 21 & 0,0625 & 62500 & 3,034 \\
\hline 29 & 336 & 33 & 0,098214 & 98214,29 & 2,792 \\
\hline 30 & 336 & 26 & 0,077381 & 77380,95 & 2,923 \\
\hline average & 336 & 38,3 & 0,11399 & 113988 & 2,722 \\
\hline
\end{tabular}

From the results of calculations that have been carried out as in the table above, it is found that the average value of DPMO (Defect Per Million Oppurtunies) is 113,988 and has an average sigma value of 2,722 sigma. 3 sigma,

\subsection{Analyze}

At this stage 2 analysis tools are used, namely the Pareto diagram and the causal diagram. Analyze Pareto diagram is used to find out the most dominant type of damage and must be treated first. After knowing the most dominant defect, Analyze using the cause and effect diagram, this diagram is used to determine the causal factors for product defects during the production of INNO cigarettes[11].

a. Pareto diagram analysis

After calculating the number of defects, analysis is carried out using the Pareto diagram. The following is a pareto diagram of the number of defects to determine the most dominant defect. 


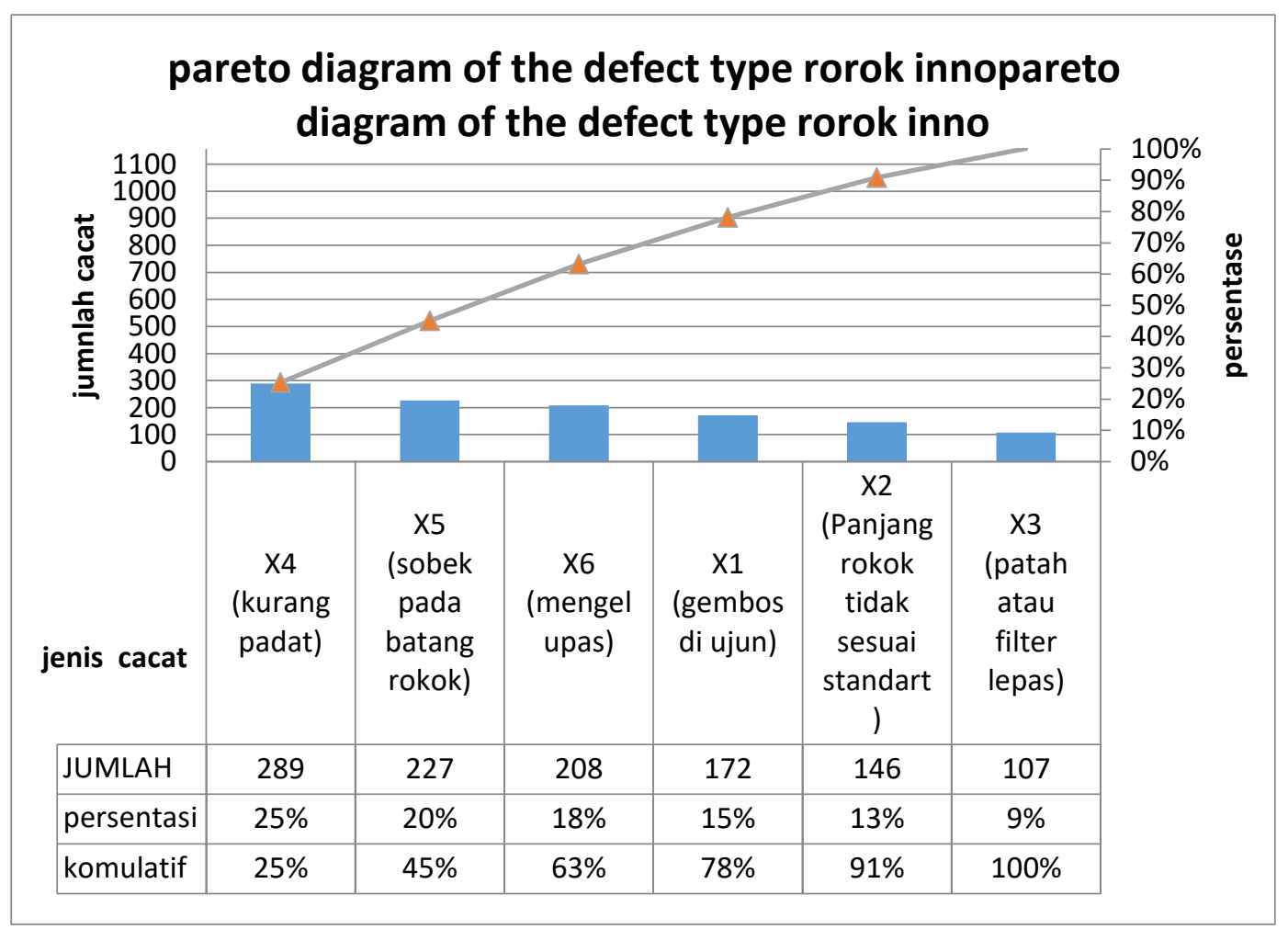

Figure 1 The Pareto diagram

Based on the results of the analysis using the Pareto diagram as shown above, it shows that the defects that are most dominant or that often occur and must be handled first are 289 less dense cigarettes with a percentage of $25 \%, 227$ pieces of torn cigarettes with a percentage of $20 \% 208$ cigarettes peeled off with a percentage of $18 \%$ b. Cause and effect diagram analysis

Causal diagrams are made based on observations in the field, interviews with workers and company owners. The following is the presentation of the cause and effect diagram of the most dominant inno cigarette product defects

Cigarettes are less dense

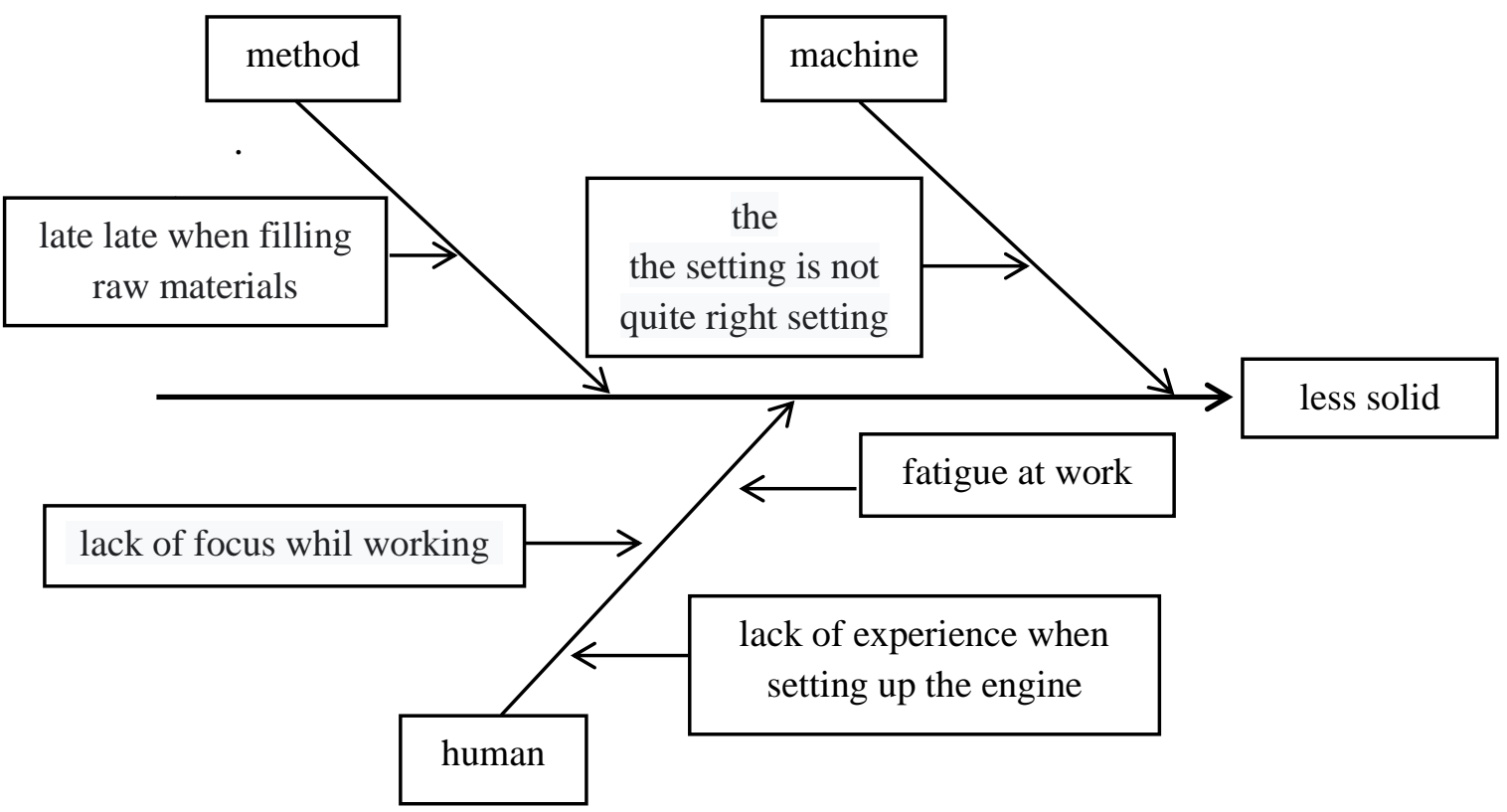


Tears on the cigarette

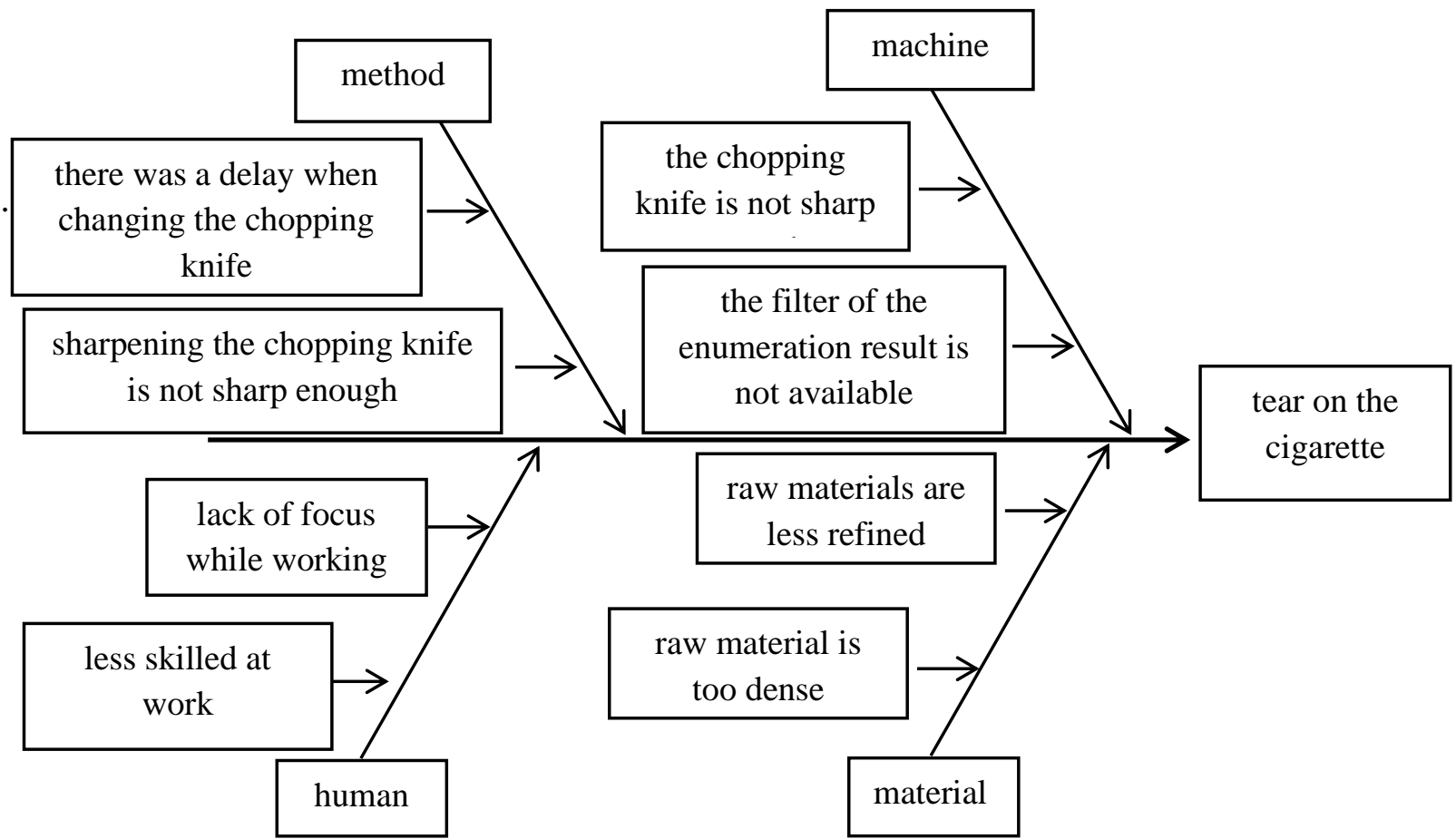

The cigarette is peeling off

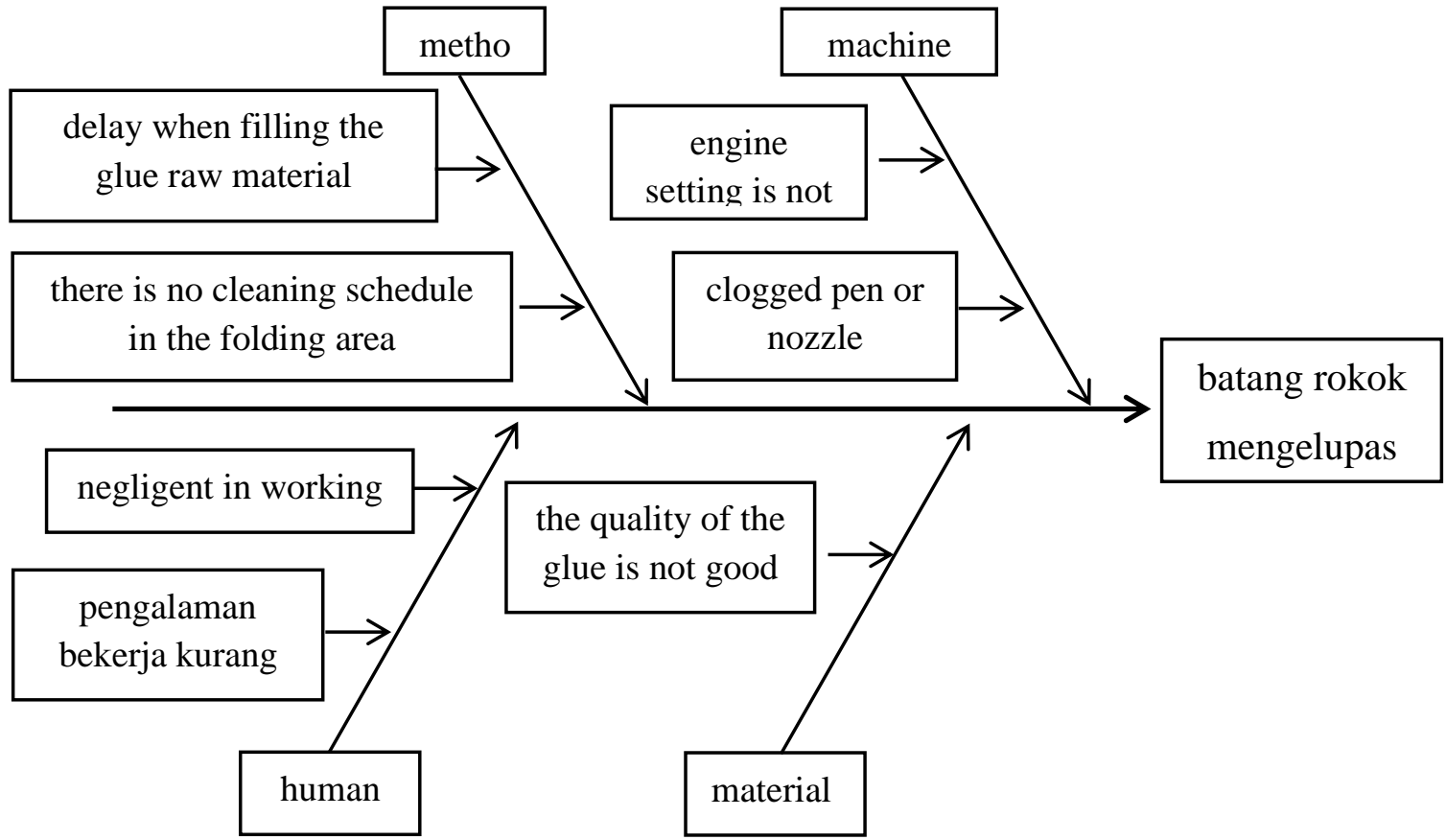

\subsection{Improve}

The improve stage is an action to carry out improvements and improvement of Six sigma quality[12]. After knowing the factors that cause damage to the types of defects in inno cigarette products from the analysis of the cause and effect diagram, then a recommendation or recommendation for general corrective action is drawn up in an effort to reduce the amount of damage that has occurred to INNO cigarette products. The following are suggestions that can 
be implemented by the company as an action to improve the quality of inno cigarettes based on the factors causing the defect.[13]

Table 3 Guidelines for Corrective Actions

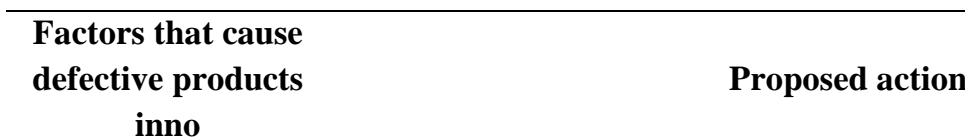

\begin{tabular}{lll}
\hline Human & $\begin{array}{l}\text { Provide training to machine operators and employees on a } \\
\text { regular basis to increase employee productivity }\end{array}$ \\
\hline Method & $\begin{array}{l}\text { Check the raw material, chopping machine, and the remaining } \\
\text { glue in the teat is still suitable for use or not before starting the } \\
\text { production process. } \\
\text { Cleaning scheduling in the folding area must be considered } \\
\text { because it greatly affects the nozzle condition, if the nozzle is } \\
\text { dirty either due to dust or something else, the gluing process to } \\
\text { the cigarette stick will be disturbed }\end{array}$ \\
machine & $\begin{array}{l}\text { Check and check the engine components, pen or nozzle and raw } \\
\text { chopper before the production process starts, and reset the } \\
\text { machine if there are inappropriate settings. }\end{array}$ \\
\hline material & Reprocessing less refined tobacco Raw materials. \\
\hline Using good quality glue or Standard.
\end{tabular}

\subsection{Control}

The control stage is the last operational stage in improving the quality of Six sigma (DMAIC)[14]. At this stage, observations and recalculation of the results of implementation will be carried out as a comparison of the results before and after implementation. The following is the sampling data after improvement[15].

Table 4 Sampling data after repair

\begin{tabular}{|c|c|c|c|c|c|c|c|}
\hline \multirow{2}{*}{ Sample } & \multicolumn{6}{|c|}{ Type of defect } & \multirow{2}{*}{ amount } \\
\hline & $\mathrm{X} 1$ & $\mathrm{X} 2$ & $\mathrm{X} 3$ & $\mathrm{X} 4$ & $\mathrm{X} 5$ & X6 & \\
\hline 336 & 9 & 2 & 8 & & 4 & 10 & 33 \\
\hline 336 & 7 & & 2 & 12 & 6 & 3 & 30 \\
\hline 336 & & 9 & 1 & 2 & 8 & 7 & 27 \\
\hline 336 & & 2 & & & 9 & 13 & 24 \\
\hline 336 & 6 & 4 & 6 & 17 & 3 & 2 & 38 \\
\hline 336 & & 13 & & 4 & 6 & & 23 \\
\hline 336 & 4 & & 2 & 7 & & 4 & 17 \\
\hline 336 & 2 & 7 & 5 & & 5 & 13 & 32 \\
\hline 336 & 8 & & & 9 & 12 & & 29 \\
\hline 336 & 6 & 3 & 7 & 2 & & 4 & 22 \\
\hline 336 & 3 & 6 & & & 4 & 9 & 22 \\
\hline 336 & 11 & & & 6 & & & 17 \\
\hline 336 & 5 & 7 & 2 & & 9 & 14 & 37 \\
\hline 336 & 3 & & 10 & 11 & 15 & & 39 \\
\hline 336 & 10 & 2 & & 7 & & 3 & 22 \\
\hline 336 & 3 & 5 & & & 8 & & 16 \\
\hline 336 & & & 9 & 13 & & 4 & 26 \\
\hline 336 & & & 2 & 1 & 6 & 12 & 21 \\
\hline 336 & 3 & 3 & & 10 & & 9 & 25 \\
\hline 336 & 2 & 7 & 4 & 7 & 11 & & 31 \\
\hline 336 & 4 & 1 & & 11 & 2 & 10 & 28 \\
\hline
\end{tabular}




\begin{tabular}{cccccccc}
336 & & & 2 & 2 & 11 & & 15 \\
\hline 336 & 6 & 2 & & & 2 & & 10 \\
\hline 336 & 2 & 5 & 3 & 3 & & 2 & 15 \\
\hline 336 & & 2 & 8 & 5 & 4 & 6 & 25 \\
\hline 336 & 6 & 4 & 2 & 17 & 2 & & 31 \\
\hline 336 & 4 & 9 & & 9 & & 2 & 24 \\
\hline 336 & 2 & 2 & 3 & 5 & 4 & 9 & 25 \\
\hline 336 & 14 & & 7 & 12 & 2 & & 35 \\
\hline 336 & 6 & 6 & 4 & & 11 & 5 & 32 \\
\hline $\mathbf{1 0 . 0 8 0}$ & $\mathbf{1 2 6}$ & $\mathbf{1 0 1}$ & $\mathbf{8 7}$ & $\mathbf{1 7 2}$ & $\mathbf{1 4 4}$ & $\mathbf{1 4 1}$ & $\mathbf{7 7 1}$ \\
\hline
\end{tabular}

From the Table 4, the number of defects can be as many as 771 defects during sampling. Then, the Table 5 presented the DPMO value and sigma level after improvement

Table 5 calculation of the DPMO value and Sigma Level after improvement

\begin{tabular}{|c|c|c|c|c|c|}
\hline observation to & Sample & Number of defects & DPO & DPMO & LEVEL SIGMA \\
\hline 1 & 336 & 33 & 0,09821429 & 98214,29 & 2,79179 \\
\hline 2 & 336 & 30 & 0,08928571 & 89285,71 & 2,84517 \\
\hline 3 & 336 & 27 & 0,08035714 & 80357,14 & 2,90267 \\
\hline 4 & 336 & 24 & 0,07142857 & 71428,57 & 2,96523 \\
\hline 5 & 336 & 38 & 0,11309524 & 113095,2 & 2,71023 \\
\hline 6 & 336 & 23 & 0,06845238 & 68452,38 & 2,98742 \\
\hline 7 & 336 & 17 & 0,05059524 & 50595,24 & 3,13911 \\
\hline 8 & 336 & 32 & 0,09523810 & 95238,1 & 2,80917 \\
\hline 9 & 336 & 29 & 0,08630952 & 86309,52 & 2,86384 \\
\hline 10 & 336 & 22 & 0,06547619 & 65476,19 & 3,01036 \\
\hline 11 & 336 & 22 & 0,06547619 & 65476,19 & 3,01036 \\
\hline 12 & 336 & 17 & 0,05059524 & 50595,24 & 3,13911 \\
\hline 13 & 336 & 37 & 0,11011905 & 110119 & 2,72590 \\
\hline 14 & 336 & 39 & 0,11607143 & 116071,4 & 2,69486 \\
\hline 15 & 336 & 22 & 0,06547619 & 65476,19 & 3,01036 \\
\hline 16 & 336 & 16 & 0,04761905 & 47619,05 & 3,16839 \\
\hline 17 & 336 & 26 & 0,07738095 & 77380,95 & 2,92291 \\
\hline 18 & 336 & 21 & 0,06250000 & 62500 & 3,03412 \\
\hline 19 & 336 & 25 & 0,07440476 & 74404,76 & 2,94375 \\
\hline 20 & 336 & 31 & 0,09226190 & 92261,9 & 2,82695 \\
\hline 21 & 336 & 28 & 0,08333333 & 83333,33 & 2,88299 \\
\hline 22 & 336 & 15 & 0,04464286 & 44642,86 & 3,19918 \\
\hline 23 & 336 & 10 & 0,02976190 & 29761,9 & 3,38430 \\
\hline 24 & 336 & 15 & 0,04464286 & 44642,86 & 3,19918 \\
\hline 25 & 336 & 25 & 0,07440476 & 74404,76 & 2,94375 \\
\hline 26 & 336 & 31 & 0,09226190 & 92261,9 & 2,82695 \\
\hline 27 & 336 & 24 & 0,07142857 & 71428,57 & 2,96523 \\
\hline 28 & 336 & 25 & 0,07440476 & 74404,76 & 2,94375 \\
\hline 29 & 336 & 35 & 0,10416667 & 104166,7 & 2,75816 \\
\hline 30 & 336 & 32 & 0,09523810 & 95238,1 & 2,80917 \\
\hline average & 336 & 25,7 & 0,076488095 & 76488,1 & 2,94715 \\
\hline
\end{tabular}


Based on the results of the above calculations, the DPMO value is 76488.1 and the sigma value is 2.94715[16]. The comparison table of DPMO values and sigma levels before and after the repair can be seen in the Table 6 .

Table 6 comparison of DPMO values and Sigma levels before and after improvement

\begin{tabular}{ccc}
\hline Parameter & $\begin{array}{c}\text { Before } \\
\text { implementation }\end{array}$ & $\begin{array}{c}\text { After } \\
\text { implementation }\end{array}$ \\
\hline $\begin{array}{c}\text { DPMO } \\
\text { Value }\end{array}$ & 113988,1 & 76488,1 \\
\hline $\begin{array}{c}\text { Sigma } \\
\text { level }\end{array}$ & 2,722 & 2,94715 \\
\hline
\end{tabular}

From the comparison table above, it can be seen that the DPMO value has decreased and the Sigma Level has increased. The DPMO value has decreased from 113988.1 to 76488.1 . And the sigma level has increased from 2,722 to 2,94715

\section{Conclusion}

Based on research conducted at the Bima Mandiri Rembang Cigarette Company in Pasuruan Regency in August 2020, in an effort to minimize product defects by applying the six sigma method with the DMAIC stage. Then the following conclusions can be drawn:

After collecting and analyzing the data, it is found that there are several factors that cause the occurrence of defects in cigarette products, namely human factors, machine methods and materials. The application of the six sigma method (DMAIC) in the Bima Mandiri Rembang cigarette company in Pasuruan district can reduce the number of cigarette defects. This can be seen from the decrease in the DPMO value from 113988.1 to 76488.1 and the sigma level has increased from 2.722 to 2.94715 [17]. in this case the quality of cigarettes is increasing with the decrease in the DPMO value and the increase in the sigma level.

\section{Reference}

1. Pratiwi ZI, Aksioma DF (2019) Pengendalian Kualitas Multivariat Pada Produksi Rokok "W" di PT. I. J. Sains dan Seni ITS 7:

2. Ghani IA, Handriyono, Wahyono H (2016) Analisis Metode Six Sigma dalam Pengendalian Kualitas Produk Rokok SKM PR. Gagak Hitam Bondowoso Gagak
Hitam. Artik. Mhs. 2016

3. Naumar A, Shahril M, Rahman A, Mohammed AH, Shareena S, Azis A (2021) Factors Affecting Participation In A Community- Based Program : Padang CityWest Sumatra' S Experience. Journal of Sustainable Technology and Applied Science (JSTAS) 2:31-36

4. Laricha Salomon L, dan Nickholaus Denata Limanjaya A, Kunci K (2015) Strategi Peningkatan Mutu Part Bening Menggunakan Pendekatan Metode Six Sigma (Studi Kasus: Department Injection Di Pt. Kg). J Ilm Tek Ind 3:156-165

5. Widiyawati S, Assyahlafi S (2017) Perbaikan Produktivitas Perusahaan Rokok Melalui Pengendalian Kualitas Produk dengan Metode Six Sigma. J Ind Eng Manag 2:32

6. Nasution MN (2015) Manajemen Mutu Terpadu (Total Quality Management). Ghalia Indonesia.

7. Kurniawan D (2019) Penurunan Produk Cacat Dengan Metode Six Sigma Dan Continuous Improvement Di PT. Cakra Guna Cipta. J Teknol Dan Manaj Ind 5:814

8. Didiharyono D, Marsal M, Bakhtiar B (2018) Analisis Pengendalian Kualitas Produksi Dengan Metode Six-Sigma Pada Industri Air Minum PT Asera Tirta Posidonia, Kota Palopo. Sainsmat J Ilm Ilmu Pengetah Alam 7:163

9. Ghea Manda Karenza, Hari Adianto GPL (2016) Pengurangan Jumlah Produk Cacat Kue Kering Nastar Keju. Pengurangan Jumlah Prod Cacat Kue Kering Nastar Keju Di Pt Bonli Cipta Sejah Menggunakan Metod Six Sigma 4:14-23

10. Idris I, Sari RA, Wulandari, U W (2016) Pengendalian Kualitas Tempe Dengan Metode Seven Tools. Teknovasi 3:66-80

11. Wiswandani A, Statistika D, Matematika F, Data S (2019) Analisis Pengendalian Kualitas pada Proses Making Produksi Diplomat Mild Reborn di PT . Gelora Djaja Surabaya. 8:2-9

12. Wisnubroto P, Rukmana A (2015) Pengendalian Kualitas Produk Dengan Pendekatan Six Sigma Dan Analisis Kaizen Serta New Seven Tools Sebagai Usaha Pengurangan Kecacatan Produk. J Teknol 8:65-74

13. Sirine H, Kurniawati EP (2017) Pengendalian Kualitas Menggunakan Metode Six Sigma (Studi Kasus pada PT Diras Concept Sukoharjo). AJIE-Asian J Innov Entrep 02:2477-3824

14. Elmas M (2017) Pengendalian kualitas 
dengan menggunakan metode SQC. J Penelit Ilmu Ekon 7:15-22

15. Wirawati SM (2019) Analisa Pengendalian Kualitas Batubara Dengan Metode Seven Tools Di Receiving Line CPCT (Coal Preparation And Coke Transportation) PT Krakatau Posco Cilegon. J Rekayasa, Teknol dan Sains 3:9-12

16. Supriyadi, Ramayanti G, Roberto AC (2017) Analisis Kualitas Produk dengan Pendekatan Six Sigma. Prosiding SNTI dan SATELIT. Univ Serang Raya 2017:7-13

17. Devani V, Wahyuni F (2017) Pengendalian Kualitas Kertas Dengan Menggunakan Statistical Process Control di Paper Machine 3. J Ilm Tek Ind 15:87 